\title{
Selection of optimal conditions for solid bonding of the AlSi11 aluminium alloy
}

\section{Dobór optymalnych warunków konsolidacji plastycznej stopu AlSi11}

\begin{abstract}
In the present work, the optimal conditions for solid bonding of fragmented aluminum alloy were determined. The research was conducted on metal chips from the AISi11 TM aluminum alloy after the turning process. The selection of proper bonding conditions was based on the results of tensile tests and surface quality analysis of as-extruded profiles. The extrusion process was conducted within a temperature range of $350-500^{\circ} \mathrm{C}$, with a ram speed of $13 \mathrm{~mm} / \mathrm{s}$. Extrusion ratio $\lambda$ was 25 . As a reference material, a sample from the solid AISi11 IM alloy has been extruded under the same conditions.

The influence of temperature during direct extrusion on both maximum force and surface quality of obtained profiles has been determined. With reference to tensile test results, no significant influence of temperature on the mechanical properties has been noticed. Profiles extruded at $500^{\circ} \mathrm{C}$ were characterized by visible cracks on the surface, oriented perpendicular in the direction of extrusion. Moreover, surface flaws were also noticed in profiles extruded at $350^{\circ} \mathrm{C}$. A tensile test revealed a strong relationship between the extrusion conditions and plasticity of solid bonded rods. A shiny and smooth surface was obtained only in profiles extruded at a temperature range of $400-450^{\circ} \mathrm{C}$.
\end{abstract}

Keywords: AlSi11, solid bonding, surface quality

\section{Streszczenie}

W niniejszej pracy określono optymalne parametry procesu konsolidacji plastycznej drobnych form aluminium. Badaniu poddano wióry ze stopu AISi11 (AK11 TM) otrzymane w procesie toczenia. Doboru optymalnych warunków konsolidacji plastycznej dokonano na podstawie własności

Łukasz Wzorek Ph.D. Eng., Mateusz Wędrychowicz M.Sc. Eng., Tomasz Skrzekut M.Sc. Eng., Piotr Noga M.Sc. Eng., Marcel Wiewióra M.Sc. Eng., Jakub Wiewióra M.Sc. Eng., Wojciech Sajdak M.Sc. Eng., Maria Richert Ph.D. D.Sc. Eng.: AGH University of Science and Technology, Faculty of Non-Ferrous Metals, Department of Materials Science and Non-Ferrous Metals Engineering, Krakow, Poland; pionoga@agh.edu.pl 
mechanicznych oraz stanu powierzchni prasówki. Wyciskanie przeprowadzono na prasie współbieżnej w zakresie temperatur $350-500^{\circ} \mathrm{C}$ z prędkością stempla $13 \mathrm{~mm} / \mathrm{s}$. Stopień przerobu wynosił $\lambda=25$. Jako materiał porównawczy wyciśnięto $w$ tych samych warunkach materiał lity AISi11 (AK11 IM) o tej samej masie.

Określono wpływ temperatury wyciskania współbieżnego na siły maksymalne w procesie oraz jakość powierzchni przy użyciu SEM. Dodatkowo wyznaczono własności mechaniczne w próbie jednoosiowego rozciągania uzyskanych profili. Nie zaobserwowano znaczącego wpływu temperatury procesu na otrzymane własności wytrzymałościowe oraz plastyczne. Powierzchnia profili wyciskanych w $500^{\circ} \mathrm{C}$ charakteryzowała się prostopadłymi pęknięciami do kierunku wyciskania. Wady powierzchniowe zaobserwowano również w prętach wyciskanych $w$ temperaturze $350^{\circ} \mathrm{C}$. Badania wytrzymałościowe wykazały silny wpływ warunków konsolidacji na własności plastyczne profili otrzymanych z wiórów AISi11. Pręty wyciśnięte w temperaturze $400^{\circ} \mathrm{C} \mathrm{i} 450^{\circ} \mathrm{C}$ cechowały się gładką i błyszczącą powierzchnią.

Słowa kluczowe: AlSi11, konsolidacja plastyczna, jakość powierzchni

\section{Introduction}

With its origins dating back to $3400 \mathrm{BC}$, recycling of metallic materials is one of the fastest growing industries today [1]. Currently, most metals are recovered by recycling, to mention only copper, silver, gold, platinum, aluminum, and their alloys [2]. Problems usually arise when fine fragments of the scrap of aluminium and its alloys (such as thin wires, foils, or post-machining chips) are to be processed [1]. The tendency towards strong oxidation and the highly developed surface of these fine fractions cause losses during traditional remelting, reaching even $60 \%$ [3]. A unique solution is in this case the process of solid bonding described in numerous publications [4-10]. The aim of solid bonding is to create a strong and long-lasting connection between the fragmented pieces of a solid body. This is possible through the application of severe plastic deformation without the need for diffusion mass transfer and with zero involvement of the liquid phase [11]. Among various technologies, it is the process of hot extrusion that can provide the required degree of plastic deformation. A fundamental aspect of the extrusion process is the proper choice of extrusion conditions, temperature, and speed - in particular, since all of them are responsible for the satisfactory mechanical properties and surface quality obtained at the lowest possible expenditure of energy in the resulting semi-finished or final products.

The aim of this article was to show the effect of extrusion temperature on maximum force, surface quality, and mechanical properties of the casting AISi11 alloy processed by direct extrusion, where the solid material has been designated as IM and large chips from the turning process as TM. Al-Si alloys are characterized by satisfactory castability, machinability, and corrosion resistance, and as such, have been widely used as a material of choice for various structural components, especially in motor vehicles [12]. However, lamellar precipitates of silicon adversely affect the ductility of these materials, forcing the use of modifiers [13-16]. An alternative is the combination of machining and solid 
bonding, which is expected to refine the silicon phase and allow the use of waste in the form of chips. The choice of this particular material was dictated by the fact that more than $90 \%$ of all aluminium castings in the world are made from aluminium-silicon alloys, and large volumes of the waste originate from the process of machining these castings (skinning, turning, milling).

\section{Research methodology}

The test material was a casting AISi11 alloy in the solid form (AISi11 IM) and in the form of chips/turnings (AISi11 TM) made in a laboratory using a TUM 35 lathe without cooling emulsion (Fig. 1a). The collected chips were pre-compacted to billets of $38.5 \mathrm{~mm}$ diameter and $10 \mathrm{~mm}$ height, with the compaction degree reaching $80 \%$ of the theoretical density of the solid material (Fig. 1b). The operation of pre-compaction was performed at room temperature in a specially prepared die, applying a pressing force of $300 \mathrm{kN}$.

a)

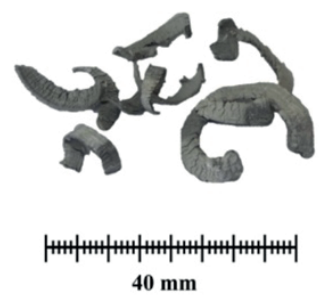

b)

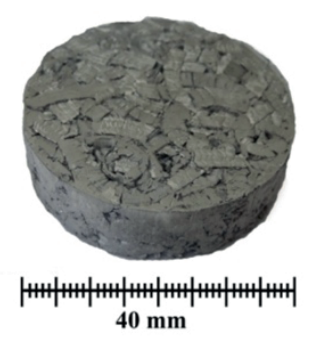

Fig. 1. Material after machining in a form of a) large chips and b) pre-compacted billet

The feedstock for the extrusion process was prepared in batches of $180 \mathrm{~g}$, and this weight was kept constant for both solid material and compacted chips. Thus, the prepared feedstock was placed in the recipient of a hydraulic press operating at a maximum ram pressure of $1 \mathrm{MN}$, where it was heated to $350^{\circ}, 400^{\circ}, 450^{\circ}$, and $500^{\circ} \mathrm{C}$. To obtain a homogeneous temperature distribution within the entire volume of the processed material, it was kept in the recipient for ten minutes and then pressed against the die walls for a further ten minutes. In the case of the fragmented fraction, this operation enabled us to obtain a density comparable to the density of solid material. Profiles were extruded in a die with an 8-mm diameter with an extrusion ratio of $\lambda=25$. The extrusion process was performed at a ram speed of $13 \mathrm{~mm} / \mathrm{s}$, each time recording the path, strength, and temperature. The surface of resulting rods was examined under a Hitachi SU-70 scanning electron microscope (SEM). Mechanical properties were determined on 5 -fold samples in the uniaxial tensile test. The deformation rate for the parallel sample length was $8 \cdot 10^{-3} 1 / \mathrm{s}$. For comparison, tests were also carried out on a reference sample obtained by gravity casting into a steel die (AlSi11 CM). 


\section{Forces operating in direct extrusion}

Figure 2 shows the relationship between extrusion force and ram displacement plotted for the solid billet (AISi11 IM) of a constant weight. Figure 3 shows the same relationship plotted for the feedstock made of compacted chips (AISi11 TM). The maximum force available in the press used in the tests (i.e., $1120 \mathrm{kN}$ ) was applied to both types of feedstock (AISi11 IM and AISi11 TM) at a process temperature of $350^{\circ} \mathrm{C}$. Raising the extrusion temperature to $500^{\circ} \mathrm{C}$ allowed us to reduce the process force by nearly $40 \%$, which meant that the profile made of solid material (AISi11 IM) was extruded at a pressure of $710 \mathrm{kN}$. The situation was similar in the case of feedstock made from compacted chips. The maximum extrusion forces are compared in Table 1 for both types of feedstock at different extrusion temperatures. The obtained extrusion force-ram path relationship changes its course depending on the type of feedstock used. For compacted chips, the initial part of the graph assumes a non-linear run, thus resembling the graph plotted for the extruded solid billet. This is due to pre-compaction of the extruded material before forcing it through the die orifice. Comparing the shape of the $F=f(s)$ function plotted for both tested materials, a slight effect of the feedstock morphology on the forcerelated parameters of the extrusion process was observed. Regardless of process temperature, the maximum force recorded for the AlSi11 TM alloy was by approx. $100 \mathrm{kN}$ lower than the maximum force recorded for the solid material each and every time.

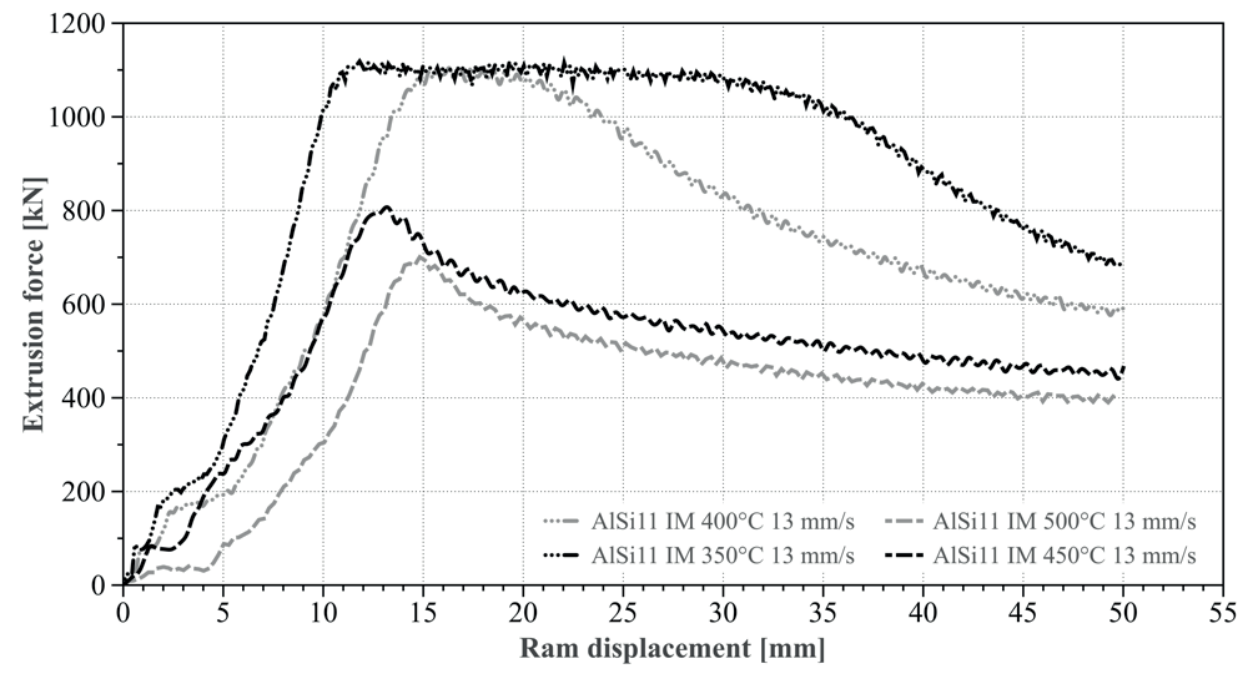

Fig. 2. Force characteristics as a function of ram displacement during extrusion of the AISi11 IM alloy 


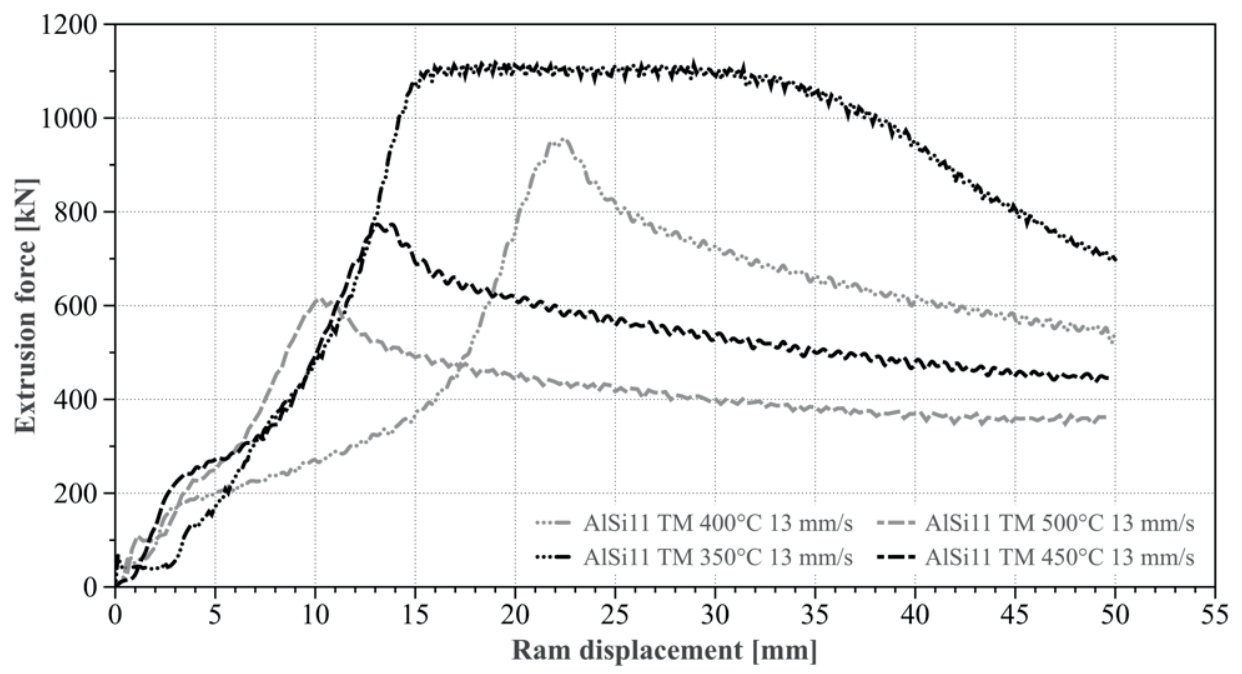

Fig. 3. Force characteristics as a function of ram displacement during extrusion of the AISi11 TM alloy

Table 1. Maximum forces in a temperature range of $350^{\circ}$ to $500^{\circ} \mathrm{C}$ during extrusion of the AISi1 1 IM and AlSi11 TM alloys

\begin{tabular}{|c|c|c|}
\hline Material & Temperature $\left[{ }^{\circ} \mathbf{C}\right]$ & Maximum force $[\mathbf{k N}]$ \\
\hline AlSi11 IM & \multirow{2}{*}{350} & 1120 \\
\cline { 1 - 1 } AlSi11 TM & & 1120 \\
\cline { 1 - 1 } AlSi11 IM & \multirow{2}{*}{400} & 1100 \\
\cline { 1 - 1 } AISi11 TM & \multirow{2}{*}{450} & 950 \\
\cline { 1 - 1 } AlSi11 IM & \multirow{2}{*}{500} & 800 \\
\cline { 1 - 1 } AISi11 TM & & 770 \\
\cline { 1 - 1 } AlSi11 IM & \multirow{2}{*}{500} \\
\cline { 1 - 1 } AISi11 TM & & 610 \\
\hline
\end{tabular}

\section{Surface quality of rods after solid bonding}

Surfaces of the extruded rods were examined by scanning electron microscopy to identify possible defects. For this purpose, a comparison was made between rods extruded from the solid AISi11 IM billet and those extruded from the compacted AISi11 TM chips. For profiles made at the same temperature from solid material and from compacted chips, a similar surface quality was obtained, as further confirmed by macro- and microscopic images (Fig. 4). 
Solid material

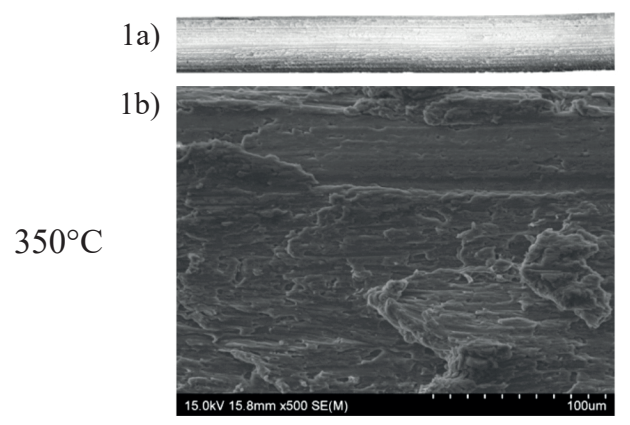

1c)

1d)

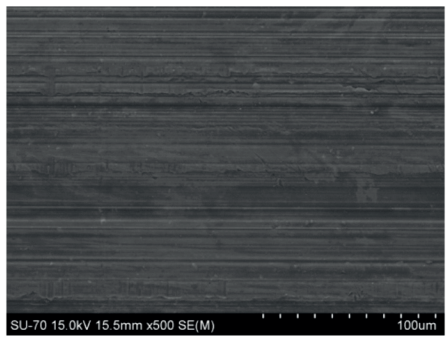

1e)

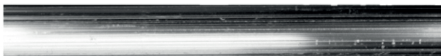

$450^{\circ} \mathrm{C}$

1f)

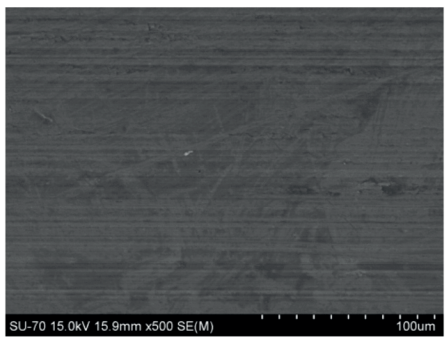

$1 \mathrm{~g})$

1h)

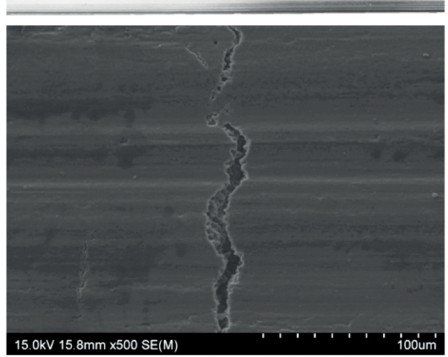

2a)

2b)
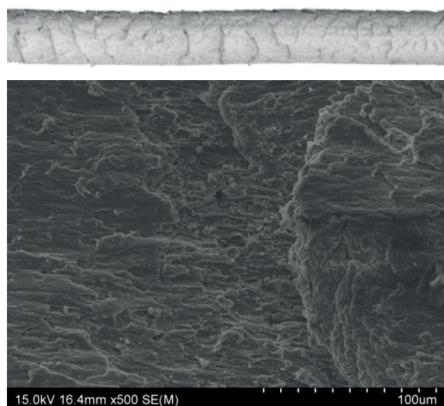

2c)

2d)

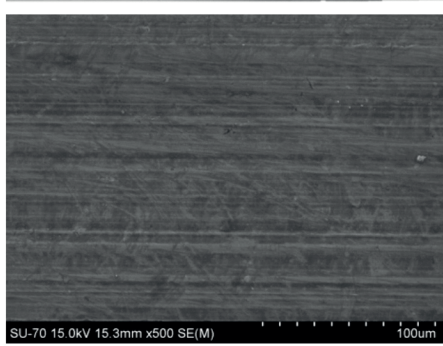

2e)

2f)

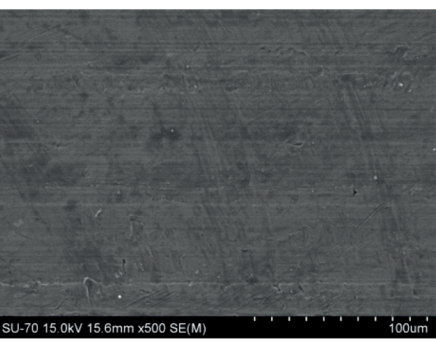

$2 \mathrm{~g}$

2h)
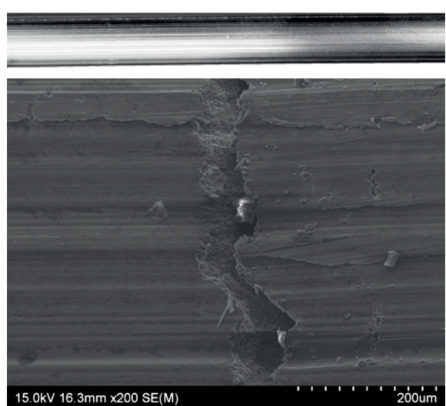

Fig. 4. Surfaces of extruded rods 
Well-visible was the effect of extrusion temperatures on the surface quality of the extruded rods. Profiles extruded at $350^{\circ} \mathrm{C}$ (Fig. 4.1a, 4.1 b, 4.2a, 4.2b) were characterized by defects in the form of unbonded portions of material elongated in the direction of extrusion. Additionally, the resulting surface was dull and had visible cracks, which made further operations of plastic working impossible. For both AISi11 IM and AISi11 TM, raising the extrusion temperature by $50^{\circ}$ and $100^{\circ} \mathrm{C}$ eliminated the defects occurring in profiles extruded at $350^{\circ} \mathrm{C}$ (Fig. 4.1c-4.1f, 4.2c-4.2f). The entire surface of the semi-finished and final products became smooth and shiny. In both cases, however, a further increase of the extrusion temperature to $500^{\circ} \mathrm{C}$ resulted in the formation of cracks running perpendicular to the direction of extrusion (Fig. 4.1g, 4.1h, 4.2g, 4.2h). The appearance of these defects was the consequence of an excessively high temperature, which caused partial surface melting in the extruded products. SEM examinations of the extruded surfaces enabled us to determine the depth of the cracks in the intermediate and final products, which amounted to approx. $0.4 \mathrm{~mm}$ for the solid material (AISi11 IM) and approx. $0.8 \mathrm{~mm}$ for the extruded chips (AISi11 TM).

\section{Mechanical properties}

For the determination of mechanical properties, a uniaxial tensile test was used. From each sample of the extruded material, three samples with a diameter of $5 \mathrm{~mm}$ and a gauge length of $25 \mathrm{~mm}$ were prepared. Figure 5 shows an example of the stress-strain curves plotted for the as-extruded solid alloy and for the cast reference AISi11 CM alloy. The highest mechanical properties were obtained in the alloys extruded at $450^{\circ}$ and $500^{\circ} \mathrm{C}\left(R_{m}-220 \mathrm{MPa}\right.$ and $\left.R_{p 0.2}-90 \mathrm{MPa}\right)$. For materials produced at $400^{\circ}$ and $350^{\circ} \mathrm{C}$, these values were lower by about $10 \mathrm{MPa}$. The total deformation obtained in all of the extruded solid rods amounted to approx. $16 \%$.

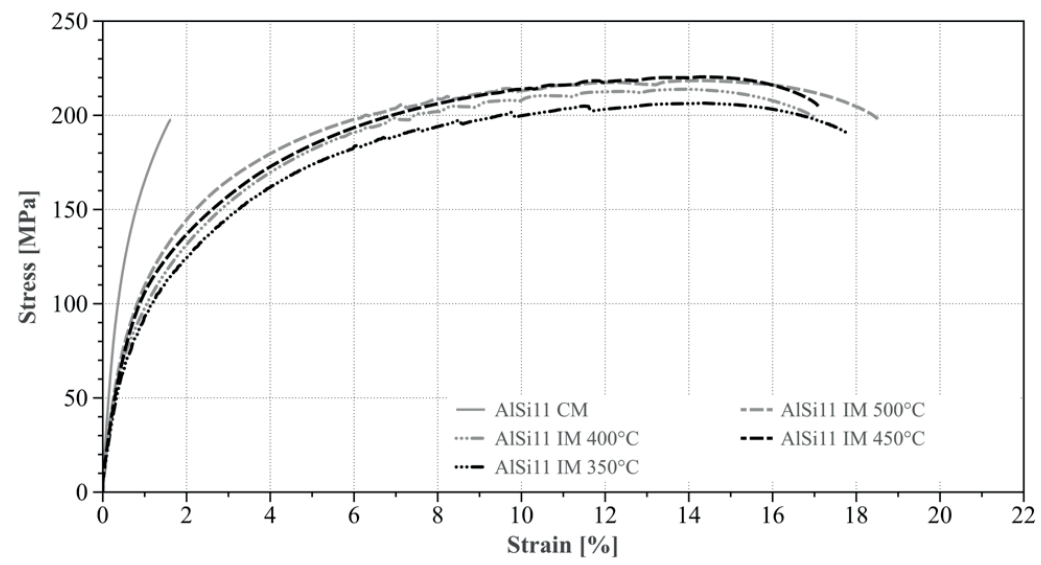

Fig. 5. Stress-strain curves plotted for the solid AlSi11 alloy extruded at different temperatures and for the reference material gravity cast into a steel die 
A similar study was carried out for rods extruded from the chips (Fig. 6). In this case, the highest mechanical properties were obtained in the rod extruded at $500^{\circ} \mathrm{C}$. The values of the tensile strength and yield strength were $212 \mathrm{MPa}$ and $90 \mathrm{MPa}$, respectively. Mechanical properties declined with decreasing temperatures of extrusion. At $400^{\circ}$ and $450^{\circ} \mathrm{C}$, the tensile strength was $200 \mathrm{MPa}$ while the yield strength was $80 \mathrm{MPa}$. The lowest properties, both mechanical and plastic, were obtained in the rod processed at $350^{\circ} \mathrm{C}$ with total elongation amounting to $13 \%$ at $R_{m}=190 \mathrm{MPa}$ and $R_{p 0.2}=80 \mathrm{MPa}$. Comparing materials extruded at the same temperature from the solid billet and feedstock composed of chips, it was observed that the mechanical properties of materials subjected to solid bonding were inferior (by approx. 8\%) to the properties obtained in the solid feedstock.

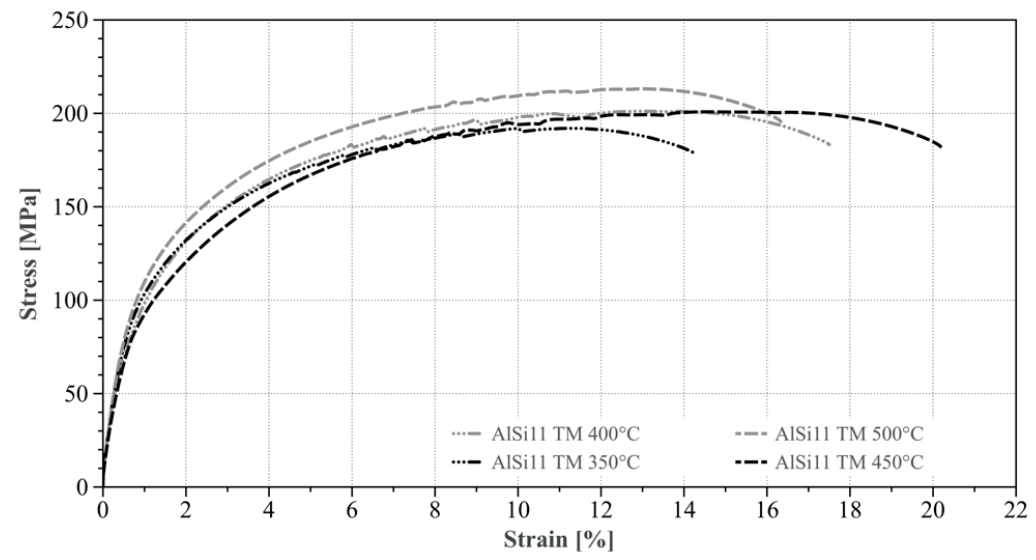

Fig. 6. Stress-strain curves plotted for the feedstock composed of AlSi11 alloy chips extruded at different temperatures

\section{Conclusions}

1. Raising the temperature to $500^{\circ} \mathrm{C}$ allowed us to reduce the extrusion force by $40 \%$ and $45 \%$ for the solid billet and compacted chips, respectively.

2. Profiles extruded at $350^{\circ} \mathrm{C}$ from the solid AISi11 IM feedstock and compacted AISi11 TM chips were characterized by numerous surface flaws, disqualifying their use as a final product. For further plastic processing, it necessary to apply an additional surface treatment in order to remove the outer layer.

3. For both feedstock types, the process conducted at $500^{\circ} \mathrm{C}$ caused partial surface melting running over the entire rod length perpendicular to the direction of extrusion.

4. A shiny and smooth surface was obtained for each type of feedstock in a temperature range of $400^{\circ}$ to $450^{\circ} \mathrm{C}$. 
5. The effect of process temperature on the mechanical properties of profiles made from the solid material was of no major importance.

6. In the case of profiles made from chips solid bonded by extrusion (AlSi11 TM), the temperature of the process had a noticeable effect on the plastic properties of the final products. At $350^{\circ} \mathrm{C}$, the elongation percentage at the fracture was $A=12 \%$, while for the rod extruded at $450^{\circ} \mathrm{C}$, it increased to $A=18 \%$.

\section{References}

[1] Poznański K., Suchowolec M.: Znaczenie recyklingu surowców wtórnych dla polskiej gospodarki. Rudy i Metale Nieżelazne, 57, 5 (2012), 332-340

[2] Kucharski M.: Recykling metali nieżelaznych. Wydawnictwa AGH, Kraków 2010

[3] Gronostajski J., Chmura W., Gronostajski Z.: Bearing materials obtained by recycling of aluminium and aluminium bronze chips. Journal of Materials Processing Technology, 125-126 (2002), 483-490

[4] Tokarski T., Wzorek Ł.: Badania własności mechanicznych i struktury szybko krystalizowanego stopu AK11. Rudy i Metale Nieżelazne, 56, 4 (2011), 196-200

[5] Tokarski T., Wędrychowicz M., Wiewióra M.: Light metals chips recycling by plastic consolidation. Key Engineering Materials, 641 (2015), 24-29

[6] Gronostajski J.Z., Kaczmar J.W., Marciniak H., Matuszak A.: Direct recycling of aluminium chips into extruded products. Journal of Materials Processing Technology, 64, 1-3 (1997), 149-156

[7] Gronostajski J.Z, Kaczmar J.W., Marciniak H., Matuszak A.: Production of composites from Al and AlMg2 alloy chips. Journal of Materials Processing Technology, 77, 1-3 (1998), 37-41

[8] Noga P., Wzorek Ł., Wiewiora J.: The Influence of extrusion ratio on the strength of hot extruded aluminium alloy chips. 24 $4^{\text {th }}$ International Conference on Metallurgy and Materials METAL 2015, June 3-5, Brno

[9] Palimąka P., Pietrzyk S., Legomski K., Końko A.: Ekstrakcja aluminium ze zgarów pochodzących z przetopu złomów. Rudy i Metale Nieżelazne Recykling, 59, 9 (2014), 453-458

[10] Pietrzyk S., Palimąka P., Stępień M., Rogala K.: Recykling aluminium z aseptycznych opakowań kartonowych. Międzynarodowa konferencja Recykling Metali Nieżelaznych, Kraków 2016, 2-4 marca

[11] Dybiec H.: Submikrostrukturalne stopy aluminium. Uczelniane Wydawnictwa Naukowo-Dydaktyczne AGH, Kraków 2008

[12] Dybiec H., Motyka M.: Influence of grain refining on abrasive wear of submicrocrystalline Al-Si alloys. Materials Science Forum, 674 (3), 97-104

[13] Lee Y.C., Dahle A.K., St. John D.H., Hutt J.E.C.: The effect of grain refinement and silicon content on grain formation in hypoeutectic Al-Si alloys. Materials Science and Engineering A, 259, 1 (1999), 43-52

[14] Nikanorov S.P., Volkov M.P., Gurin V.N., Burenkov Yu.A., Derkachenko L.I., Kardashev B.K., Regel L.L., Wilcox W.R.: Structural and mechanical properties of Al-Si alloys obtained by fast cooling of a levitated melt. Materials Science and Engineering A, 390, 1-2 (2005), 63-69

[15] Katgerman L., Dom F.: Rapidly solidified aluminium alloys by meltspinning. Materials Science and Engineering A, 375-377 (2004), 1212-1216

[16] Shivaprasad C.G., Narendranath S., Desai V., Swami S., Ganesha Prasad M.S.: Influence of Combined Grain Refinement and Modification on the Microstructure and Mechanical Properties of Al-12Si, Al-12Si-4.5Cu Alloys. Procedia Materials Science, 5 (2014), 1368-1375 